\title{
The Effects Of Customer-Firm Interaction On Innovation And Performance In Service Firms
}

\author{
Tammy R. Huffman \\ Utah Valley University • Orem, Utah \\ Bruce C. Skaggs \\ University of Massachusetts Amherst • Amherst Massachusetts
}

\begin{abstract}
Understanding innovation in services has always been complicated by the intangibility of the underlying offering and hence the ease of imitation by rivals. This study extends the transaction cost approach by investigating how the switching costs created by the interaction between a service firm and its customers impact the level of innovation activity by the organization. Using data obtained from a sample of 221 service firms, the findings suggest that when organizations structure their service production processes in a manner that requires a high degree of direct face-to-face interaction with the customer, the resulting impact is an increase in customer switching costs. This, in turn, acts as competitive protection for these firms, inducing them to pursue greater levels of innovation. In addition, we found that certain combinations of customer-firm interaction and innovation activity led to superior performance.
\end{abstract}

\section{Introduction}

Numerous studies in the management literature have supported the idea that an emphasis on innovation can increase firm performance by leveraging dynamic capabilities (Pittaway, Robertson, Munir, Denyer, \& Neely, 2004); capturing market share (Kerin, Varadarajan, \& Peterson, 1992), exploiting experience and learning curve effects (Lee, Smith, Grimm, \& Schomburg, 2000; Porter, 1985), preempting scarce resources (Lieberman \& Montgomery 1988), creating reputation effects (Hitt, Bierman, Shimizu, \& Kochhar, 2001), and adopting a service dominant logic (Lusch, Vargo, \& O'Brien, 2007). However, scholars also acknowledge that such an emphasis may not always result in higher levels of firm performance (Lieberman \& Montgomery, 1998; Lumpkin \& Dess, 1996). This contrasting stream of research suggests that when rivals are able to imitate the products or services of a first-mover, it can adversely affect the ability of the innovator to sustain an advantage, as the imitator may be able to avoid development costs, pricing mistakes, and learn from the first mover's experience (Lee, et al., 2000; Lieberman \& Montgomery, 1998; Porter, 1985). 
The extant services literature proposes that this is of particular concern for innovators within service organizations because protecting new service innovations is difficult due to the intangibility of the offering (i.e., the service is typically a process, not a tangible product) (e.g., Song, Di Benedetto, \& Zhao, 1999). As a result, these types of firms typically cannot depend on patents or other legal protections to ensure the efficacy of their innovations (e.g., Sundbo, 1997). Thus, in order for these firms to increase their commitment to innovation, other barriers must be in place to reduce the impact of ease of imitation by rivals.

One competitive barrier in services that has received much attention in the literature is the existence of a relationship between the service firm and the customer (Gotlieb, Levy, Grewal, \& Lindsey-Mullikin, 2004; Klemperer, 1995; Lehmann \& Neuberger, 2001; Mills \& Margulies, 1980). In this study we are specifically interested in the direct face-to-face interaction between service firms and their customers. A customer-firm interaction (CF1) occurs when there is direct face-to-face contact between the consumer and the service firm (Mills, 1986; Mills \& Margulies, 1980). Interaction to varying degrees is typical for service organizations, since the simultaneous production and consumption of the offering requires these firms to interact with their customers to a greater degree than manufacturing firms (Mills, 1986; Normann, 1984). With today's technological advances, however, there are many different ways for firms to interact with customers (i.e. Internet or automated communication). Organizations must decide upon the level of direct face-to-face (CFI) interaction they will have with customers during service production. Thus, the degree of CFI is a firm-level decision and is the result of how a service organization structures its production process (Skaggs \& Huffman, 2003). For example, some insurance companies structure service production so that there is little in the way of customer interaction, performing most of their transaction via the internet or telephone. Other insurance companies open numerous branch offices and require face-to-face interactions with customers. Therefore, within the same industry firms have varying levels of $\mathrm{CFI}$.

When CFI occurs, customers are better able to gain knowledge about the abilities of their particular service provider (Mills \& Margulies, 1980). If the interaction between the customer and the provider is indirect or cosmetic (i.e., when CFI is low), the amount of knowledge the customer can gain about the provider's abilities is limited, since there is restricted interaction with the production process (Durkin, McCartan-Quinn, O'Donnell, \& Howcroft, 2003). However, if interactions are intense (i.e., when CFI is high), then a greater degree of knowledge regarding the provider's abilities at service production is acquired by the customer (Durkin, et al., 
2003). This knowledge reduces customers' perceived uncertainty surrounding the service offering as well as their search and evaluation costs when considering future purchases (Jones, Mothersbaugh, \& Beatty, 2000). Together, these act to increase the customer's perceived cost of switching to a rival's offering (e.g., Kahneman, Knetsch, \& Thaler, 1991; Rumelt 1987; Williamson, 1979). In addition, Jones, et al. (2000) found that these switching costs lead customers to stay with their current provider, even when the satisfaction with the current provider is seen as low. Thus, service organizations with high levels of CFI are more likely to retain their current customers, as the switching and evaluation costs of considering alternate suppliers, deter buyers from leaving their current provider (Rumelt, 1987).

Given that competitive barriers can increase a firm's chances for sustaining advantages from innovations, and that the level of CFI is a significant element of service transactions that can act as such a barrier, it is surprising that there has been little research investigating this relationship as defined in this paper. Thus, the present study seeks to address this deficiency by examining the impact of CFI on service firm commitment to innovation. In doing so, we incorporate elements of transaction costs analysis and prospect theory to address the following two questions: 1) Does the level of CFI impact a service firm's level of innovation activity? and 2) Will a "fit" between CFI and the level of innovation result in superior firm performance?

We begin by discussing CFI and its impact on customer-firm transactions in service organizations. Next, we discuss the influence CFI can have on a service firm's commitment to innovation. In doing so, we develop and test hypotheses that relate CFI to innovation activity, as well as the interaction of these variables to firm performance. We end with a discussion of our findings and offer directions for future research.

\section{Theory and Hypotheses}

\section{Customer-Firm Interaction and services}

The literature on CFI has its origins in the unique nature of services. One of the most often cited aspects of service organizations is the simultaneous production and consumption of the offering. Because of the intangible nature of services, these firms must interact to a greater degree with their customers than their manufacturing counterparts (Mills, 1986; Normann, 1984). During service production, an interaction occurs between the firm and its customers where information is exchanged for the purposes of producing the offering (Mills \& Margulies, 1980). The amount 
of information exchanged is a byproduct of the level of customer-firm interaction, which is determined by how a service firm chooses to structure its production process (Skaggs \& Huffman, 2003; Tansik, 1990). Thus, the degree of these interactions, and hence the level of information exchanged, varies among service providers (Mills \& Margulies, 1980; Shostack, 1987; Skaggs \& Huffman, 2003). Some service organizations may choose to produce their service in a manner such that little CFI is required, with interactions being generally indirect or automated. For service organizations that structure the production of their offering in this manner, the relationship is not so much about the production of services, but rather the dispensing of them (Mills, 1986).

Past research on CFI has been chiefly concerned with its impact on the efficiency and effectiveness of service delivery. The impetus for this concern lies in the seminal work by Thompson (1967), where he states that organizations should buffer their technological core from external disturbances in order to achieve greater effectiveness in production. Since simultaneous production and consumption in services reduces the possibility of buffering, information generated from CFI became viewed as an external disturbance that created uncertainty in the service production process (Skaggs \& Huffman, 2003; Tansik, 1990). Using this lens, researchers began to investigate ways to adapt to and/or reduce the level of the customer-induced uncertainty in service production. Areas of investigation have included the impact of this uncertainty on service production design (Skaggs \& Huffman, 2003), on service quality (Berry, Parasuraman, \& Zeithaml, 2003), and on the level of human capital required in service production (Skaggs \& Youndt, 2004).

While we believe this research has given us insight into CFI, we also believe that its focus on the firm's response to uncertainty has limited the application of this construct. As discussed above, differing levels of customer-firm interaction impart different amounts of information and uncertainty into the firm. However, we also know that during this same interaction customers gain information about their provider (Mills, 1986). When CFI is high, the in-depth interactions lead to personal exchanges between the customer and the firm (Mills, 1986; Normann 1984). While these exchanges allow the firm to access needed information from the customer, they also allow the customer to obtain greater information about the organization (Eriksson \& Vaghult, 2000). The information obtained from direct interactions allows customers to acquire knowledge regarding such things as their provider's skills, abilities, and level of commitment in providing the service in question; in short, it gives customers knowledge about the firm's overall ability at service production. Conversely, low levels of CFI grant customers minimal in- 
formation regarding the provider. As a result, customers of these types of firms know comparatively little about the abilities of the provider. We suggest that this difference in the information resulting from the level of CFI has implications for a service firm's innovation activity.

\section{CFI, Switching Costs, and Innovation}

When customers are considering the purchase of a service among competing providers, they will use available information to inform their choice. If the customer has a relationship with an existing provider, then, all else being equal, this will lead the customer to be predisposed towards the existing service firm. This is due to the customer's tendency to minimize search costs (Williamson, 1985). Since the customer has access to free information regarding his/her knowledge of the current provider, and seeking knowledge of new providers would entail some type of cost (either in money, time, and/or effort), the customer will be inclined not to change providers. Thus, any provider-specific knowledge can act as a switching cost for the customers of service firms (Bolton, Lemon, \& Verhoef, 2004; Ouchi, 1984; Rumelt, 1987; Williamson, 1985) and these switching costs have been shown to impact buyer behavior. However, what compounds this predisposition is the loss aversion bias that is present in a consumer's calculation of switching costs.

Prospect theory, a well established theory in the economics literature, states that losses have much more of an impact on people's decisions than similarly sized gains (Kahneman, et al., I991; Kahneman \& Tversky, 1979). As a result, people tend to value the assets they have more than those that they do not have, for giving up the asset in their possession for another would introduce uncertainty and hence the potential for loss. The impact of this phenomenon is that people overstate the costs of giving up an asset in their possession for another, thereby leading to a status quo effect (i.e., holding on to their current asset) (Kahneman, et al., 1990). This phenomenon is exacerbated when the relative level of uncertainty between the two assets is high; that is, when people fully understand the benefits of the asset in their possession in relation to the asset they would be trading for. However, when people have little understanding of the benefits of the asset in their possession, then the status quo effect, although still present, is reduced. Thus, the degree of the status quo effect is impacted by the relative level of uncertainty between the two assets in question.

In transaction costs terms, the status quo effect that results from uncertainty and the loss aversion bias is actually the result of increased perceived switching 
costs on the part of customers (Williamson, 1985). Numerous studies using physical products have shown that customers tend to stay with their existing product rather than switch to that of a competitor, even though the competing product may be marginally superior (e.g., Kahneman, et al., 1991). Here, the physicality of the product in their possession allows customers to have an understanding of its benefits. The thought of adopting a new product introduces uncertainty and hence increases perceived switching costs, thereby inducing customers to stay with their current product (Gourville, 2007). However, services are somewhat different. Because of the intangible nature of services where what is sold is typically a process, it is the knowledge of this process that will aid in customers' determination of the benefits derived from their current provider (cf. Mills 1986). Stated differently, what a customer gives up when switching providers is his/her familiarity with the existing provider's abilities in service production. When this familiarity is high, the benefits from the current provider are well understood. This increases the relative level of uncertainty involved in switching providers, thereby increasing the perceived switching costs. However, when knowledge of the current provider's production abilities is low, the level of relative uncertainty between current and potential providers is reduced, which in turn reduces perceived switching costs. Thus, while we know that customers generally tend to overweight their relationship with their current provider (Gourville, 2007; Kahneman, et al., 1991), we believe this effect to be greater for organizations where there are high levels of CFI. Here customers have amassed a much larger amount of knowledge and familiarity with the production process. Therefore, the perceived costs associated with switching providers will be much higher.

As stated previously, the desire of service firms to innovate is tempered by the lack of competitive barriers (Sundbo, 1997). We believe that high levels of CFI can serve as a sufficient barrier. By increasing the perceived switching costs for customers, high levels of CFI enhance the status quo effect and thereby act as an isolating mechanism for these organizations (Rumelt, 1987). Because of this competitive barrier, we believe that firms that have constructed high CFI production processes will have a greater predisposition towards innovation activity for two reasons. First, since customers overweight the benefits from their current provider, they are more likely to adopt the innovations the firm develops (Brush \& Artz, 1999). Second, due to this overweighting of benefits and hence the perceived cost of switching, customers are unlikely to change providers when other firms copy the innovation (John \& Weitz, 1988; Rumelt, 1987). In fact, switching is only likely to occur when the competing innovation is seen as vastly superior (Gourville, 2007). The result of these two factors is that the risks associated with innovation are reduced. 
Thus, we believe that service firms that utilize high levels of CFI in their production process will engage in higher levels of innovation.

Hypothesis 1: A positive relationship will exist between a service firm's level of CFI and its level of service innovation.

Hypothesis 2: A positive relationship will exist between a service firm's level of CFI and its level of delivery innovation.

We have hypothesized that the perceived switching costs associated with the level of CFI will influence a service firm's commitment to innovation. However, investing in innovation can be a costly endeavor. The expenses in research and development, marketing, altering the delivery process, retraining of employees, and the like can amount to rather large investments on the part of the organization. Given the costs, it is suggested that efficient firms will make just enough of an investment in innovation as is warranted by their level of CFI (cf. Williamson, 1979). For example, an insurance agency that requires high levels of CFI with its policy holders may be able to increase its performance via innovation due to the presence of high perceived switching costs by customers. On the other hand, an agency that requires less CFI lacks this competitive barrier. As a result it may be more likely to maximize its performance by saving on the expense of investments in innovation. Therefore, we suggest that service firms that possess a match between their level of $\mathrm{CFl}$ and innovation activity will have greater performance. Based on the expected association between CFI and innovation detailed in Hypotheses 1 and 2, we suggest the following moderated relationships:

Hypothesis 3: The level of CFI will moderate the relationship between service innovation and performance.

Hypothesis 4: The level of CFI will moderate the relationship between delivery innovation and performance.

\section{Methods}

\section{Sample}

To test our hypotheses we collected data through mail surveys and then analyzed the responses utilizing hierarchical regression. We collected data directly from service firms. We considered only those service firms that were publicly held in order to obtain published data pertaining to firm performance. Next, in accordance 
with previous innovation strategy research, we only included firms with more than $\$ 10$ million in sales and more than 50 employees in order to enhance the possibility that the organizations possessed the resources to pursue innovation activities (O'Brien, 2003). Finally, we limited our sample to only those service firms that received a minimum of $70 \%$ of their sales from a single industry (Rumelt, 1974). This restriction was applied to increase the likelihood that a firm's level of CFI and innovation activity occurred in the same industry, as well as to decrease the possibility of multiple levels of CFI within a particular firm. Using Global Access, a database containing in-depth financial information on over 12,000 companies, we identified 1,712 service organizations that met our screening criteria.

In accordance with Miller (1991) and Dillman (1978), multiple mail surveys were conducted involving the highest-ranking executive in each firm (usually the CEO, but in a few cases the President or Chief Operating Officer). Although difficult to retrieve information from top management, it is presumed that these individuals are most knowledgeable about their firms' innovation investments and structure (Barringer \& Bluedorn, 1999). A total of 1,712 questionnaires were mailed. In response, 221 organizations representing 62 different industries returned usable questionnaires, representing a $13 \%$ response rate. Though this is somewhat low, it is consistent with other studies that have used CEOs as their sample population (e.g. Skaggs \& Huffman, 2003). Furthermore, an analysis of respondent-nonrespondent bias using one-way between-groups analysis of variance involving both the number of employees and performance showed the two groups were not significantly different on either of these dimensions $(F=.679, p<.10$ and $F=1.216, p<.10)$. This result indicates that there were no significant difference between companies that responded and companies that did not. Thus, even though the response rate may be relatively low, the lack of bias indicates that the sample is representative of the broader population of firms.

\section{Measures}

There are inherent challenges to measuring innovation in service organizations. Due to the intangible nature of services, very few of these organizations pursue patents, thus rendering patent counts ineffectual as a means for measuring innovation (Miles, 2007). Also, a low percentage of these firms have stand-alone R\&D departments, which makes the use of accounting-based R\&D measures problematic (Miles, 2007; Sundbo, 1997). Finally, since innovation in services tends to occur throughout the organization rather than in a stand-alone R\&D department, identi- 
fying the specific number of innovations can be difficult (Miles, 2007). For these reasons, and in accordance with previous innovation research, we opted for the use of perceptual measures in our survey aimed at ascertaining the level of commitment a service firm has to innovation. To add granularity, we directed our commitment questions toward the two broad types of innovation that are found in the innovation literature: product and process (e.g., Barris, 1986; Damanpour \& Shanthi, 2001). Barris (1986) differentiates the two types by suggesting that a "product" is a good or service offered to a customer, while a "process" is the method of production and delivery of the good or service. These two broad types of innovation were chosen because of their consistency with the services marketing literature, which states that the two main components of the service encounter are the "outcome" dimension (the actual service that the customer receives), and the "process" dimension (how the service is delivered) (Parasuraman, Zeithaml, \& Berry 1985; Smith, Bolton, \& Wagner, 1999). Based on this classification we identified and measured two distinct dimensions of commitment to innovation within service firms: service innovation, which is the actual service the customer is purchasing, and delivery innovation, which is the process of producing and delivering the service. Thus, service innovation pertains to a service firm's level of commitment to innovation activity aimed at improving the actual service offering. This construct was measured using a six-item scale based on innovation questions developed by Miller and Friesen (1978). Cronbach's alpha coefficient was .94 , indicating that the six items were highly correlated and thus, are measuring the same thing, indicating internal consistency. Delivery innovation refers to a service firm's commitment to activity in finding new ways to deliver its services (Parasuraman, et al., 1985). This variable was measured using a three-item scale with an alpha coefficient of .83 .

Customer-firm interaction (CFI) involves both the quantity and quality of direct interaction between the customer and the firm in terms of the information exchange and the level of customer involvement during the exchange (Mills \& Margulies, 1980). Based on the typology by Mills and Margulies (1980), a four-item scale was developed to measure the level of CFI during transactions (alpha $=.80$ ). Firm performance was measured by creating a composite index that included firm ROA, ROS, and market-to-book ratio (Zhang \& Rajagopalan, 2004). This measure was developed by standardizing and summing two years of data (2002-2003) for these three performance indicators. Raw data were obtained through Thomson Analytics database. The years 2002-2003 were chosen to reduce the anomalous effects of any one year and to create a lag between the innovation variables and performance. Cronbach's alpha for this measure was .73 . 


\section{Control Variables}

A number of firm-level variables have been found to have a potential impact on innovation and performance. Therefore, our study includes several control variables to ensure that the significance of our models is the direct result of our variables of interest rather than an extraneous variable. Extant research in the area of strategy has found that the size of a firm may have an impact on firm performance due to an increase in market size and available resources (e.g., Huselid, 1995). In addition, these resources may also allow larger firms to engage in more innovation than smaller firms. In order to control for the effects of firm size, we calculated the natural $\log$ of the number of employees. Number of employees was used rather than sales, as it is believed to be a more accurate proxy of firm size in the service sector (Normann, 1984, Skaggs \& Huffman, 2003). It is also possible that the scope of a service firm's strategy could impact its level of CFI, as well as its relationship to innovation activity and performance (Craft 2004). To control for market scope, we used a three-item scale developed by Dess, Lumpkin, and Covin (1997) that measures the degree of focus of a firm's strategy (alpha $=.623$ ). Lastly, the innovation literature as well as research concerning organizational change has found that $C E O$ tenure can impact the level of innovation a firm undertakes (Bantel \& Jackson, 1989). As a result, the survey asked for the number of years the CEO had been with the company.

A number of industry-level variables have also been found to impact innovation activity and firm performance. To control for the effects of differing levels of industry performance, we developed a composite measure by combining the twoyear averages (2002 and 2003) of ROA, ROS, and market-to-book ratio for each industry at the 6-digit NAICS code level. Utilizing the approach by Boyd (1990), we controlled for munificence by calculating the regression slope coefficient divided by mean sales value found when regressing time against industry sales within a five year period (1997-2002) (Boyd, 1990; Subramaniam \& Youndt, 2005). In order to control for industry dynamism, we once again regressed time against industry sales over a five year period. We then took the standard error of the beta and divided it by mean sales for each industry. Finally, industry complexity was assessed using the MINL formula of sales concentration (Subramaniam \& Youndt, 2005). Data used in these calculations were obtained from the Census Bureau's industry reports.

To address the validity and reliability of our perceptual measures, we performed a confirmatory factor analysis using LISREL software. The Comparative Fit Index $(\mathrm{CFI})=.94$, Goodness of Fit $(\mathrm{GFI})=.88$, the Non-Normed Fit Index (NNFI) $=.93$, and the Normed Fit Index $(\mathrm{NFI})=.93$. Taken together these indices suggest 
good model fit (Lance \& Vandenberg, 2002). Construct reliability was assessed by calculating Cronbach's alpha for each of the constructs. All of the scales reached the .70 a suggested by Nunnally (1978). Moreover, the standardized loadings of all measurement items to their respective constructs were significant at the $p<.05$ level, suggesting that the scales for the constructs had convergent validity, indicating that the items for each scale were measuring the same thing (Fornell \& Larcker, 1981).

In addition to testing convergent validity or the internal consistency of a new measure, Campbell and Fiske (1959) stressed the importance of assessing discriminant validity to show that the items of a measure are not highly correlated to other measures and therefore are distinct theoretical constructs. To assess the discriminant validity of our measures, we examined the squared inter-construct correlations for each pair of constructs and compared them to the average shared variance for each construct, as suggested by Fornell and Larcker (1981). The average shared variance for each construct was greater than the squared inter-construct correlations, thus suggesting an acceptable level of discriminant validity (Fornell \& Larcker, 1981). In addition, none of the confidence intervals of the phi values contained a value of one $(\mathrm{p}<.01)$, again suggesting that the constructs possessed discriminant validity (Bagozzi \& Phillips, 1982).

One concern regarding our methodology was that while different sources were used to measure the independent and dependent variables in Hypothesis 2, Hypothesis 1 used a single source. In order to reduce the possibility of common response bias, a number of precautions were taken. Following recommendations which can be found in Podsakoff, MacKenzie, Lee, and Podsakoff (2003), we pretested the items to reduce the possibility of confusing language in the field survey. Next, to reduce the possibility of social desirability bias, respondents completed the questionnaire absent the presence of a surveyor and were assured of confidentiality. Finally, none of the items elicited affective states, which helps to control for any mood-state bias. In addition to these precautions, we used Harmon's single factor test to assess the presence of common methods bias (Podsakoff, et al., 2003). The emergence of three distinct, a priori factors suggests a reduced likelihood of this type of bias influencing our findings. Given the results of the confirmatory analysis, the precautions, and tests taken to address common methods bias, we have high confidence in the validity of our findings.

Correlations, means, and standard deviations for all variables in the study are shown in Table 1. Questionnaire items with factor loadings can be found in the Appendix. 
Table 1

Correlations, Means, and Standard Deviations

\begin{tabular}{|c|c|c|c|c|c|c|c|c|c|c|c|c|c|}
\hline & Mean & $\begin{array}{l}\text { Std. } \\
\text { Dev. }\end{array}$ & CFI & $\begin{array}{l}\text { Serv. } \\
\text { Inn. }\end{array}$ & $\begin{array}{l}\text { Del. } \\
\text { Inn. }\end{array}$ & Perform & $\begin{array}{l}\text { Dyna- } \\
\text { mism. }\end{array}$ & $\begin{array}{l}\text { Firm } \\
\text { Size }\end{array}$ & $\begin{array}{c}\text { CEO } \\
\text { Tenure }\end{array}$ & $\begin{array}{l}\text { Ind } \\
\text { Perf }\end{array}$ & $\begin{array}{l}\text { Mkt. } \\
\text { Scope }\end{array}$ & Complex & Munif. \\
\hline $\mathrm{CFI}$ & 5.109 & 1.226 & 1 & & & & & & & & & & \\
\hline $\begin{array}{l}\text { Service } \\
\text { Innovation }\end{array}$ & 4.062 & 1.114 & .161 & 1 & & & & & & & & & \\
\hline $\begin{array}{l}\text { Delivery } \\
\text { Innovation }\end{array}$ & 4.278 & 1.527 & .227 & .591 & 1 & & & & & & & & \\
\hline Performance & .132 & 2.145 & .193 & -.110 & -.031 & 1 & & & & & & & \\
\hline Dynamism & .119 & .010 &,- 097 & .106 & .057 & -.179 & 1 & & & & & & \\
\hline Firm Size & 2333 & 7023 & .023 & .170 & .017 & .068 & -.156 & 1 & & & & & \\
\hline CEO Tenure & 7.635 & 6.894 & .116 & -.053 & -.034 & .044 & .040 & -.167 & 1 & & & & \\
\hline $\begin{array}{l}\text { Industry } \\
\text { Performance }\end{array}$ & 3.004 & 4.034 & .011 & -.030 & -.010 & .243 & -.096 & -.034 & -.005 & 1 & & & \\
\hline Market Scope & 3.904 & 1.370 & -.031 & .046 & -.004 & -.010 & -.027 & -.060 & -.039 & -.075 & 1 & & \\
\hline Complexity & -19.54 & 555.1 & .058 & .092 & .019 & -.038 & -.035 & -.003 & -.027 & -.048 & .008 & 1 & \\
\hline Munificence & .052 & .077 & .001 & .014 & .053 & -.009 & .159 & -.077 & .001 & -.028 & .117 & -.098 & 1 \\
\hline
\end{tabular}

Correlations $>.141$ are significant at the $p<.05$ level. $N=221$

While the data were centered to compute the interaction terms, the means reported were derived from uncentered data. 


\section{Results}

Hierarchical regression analysis was performed to test the hypotheses of this study. This methodology allows us to assess the degree to which a change in the independent variables affects the dependent variable. The analysis required a multistep process. In the first step we included only the control variables as the independent variables. Next, we added the variables of interest into the equation as additional independent variables. This technique allows us to identify the additional significance provided by the variables we hypothesize will affect the dependent variables.

We used SPSS to conduct an ordinary least squared regression analysis to test the CFI - innovation hypotheses (Hypothesis 1 \& Hypothesis 2). As predicted, a significant relationship was found between CFI and service innovation $(b=.162$, $\mathrm{p}<.01$; see Table 2 ). In addition, the direction of the relationship was, as predicted, suggesting that higher levels of CFI do lead to increasing commitment to service innovation. Furthermore, we also found a significant relationship between CFI and delivery innovation $(b=.241, p<.01$; see Table 3$)$. The positive beta shows a relationship in the hypothesized direction such that higher levels of CFI result in higher levels of commitment to delivery innovation by service firms. Taken together, these finds give full support to Hypotheses 1 and 2 .

Table 2

Regression Results for Service Innovation

\begin{tabular}{lccc}
\hline Control & Step 1 & Step 2 & VIF \\
\hline Firm Size & $.190^{\star *}$ & $.181^{*}$ & 1.061 \\
Dynamism & $.144^{*}$ & $.159^{* *}$ & 1.062 \\
Industry Performance & .000 & .002 & 1.034 \\
CEO Tenure & .013 & .034 & 1.035 \\
Complexity & .101 & .091 & 1.032 \\
Munificence & .010 & -.005 & 1.056 \\
Market Scope & .043 & -.045 & 1.029 \\
& & & \\
Main Effects & & $.162^{\star *}$ & 1.030 \\
CFI & & .087 & \\
$\mathrm{R}^{2}$ & .058 & $.029^{* *}$ & \\
$\Delta \mathrm{R}^{2}$ & & $2.420^{* *}$ & \\
$\mathrm{~F}$ & 2.005 & $5.667^{* *}$ & \\
$\Delta \mathrm{F}$ & & & \\
\hline
\end{tabular}


Table 3

\section{Regression Results for Delivery Innovation}

\begin{tabular}{lccc}
\hline Control & Step 1 & Step 2 & VIF \\
\hline Firm Size & .034 & .020 & 1.062 \\
Dynamism & .075 & .097 & 1.071 \\
Industry Performance & .022 & .019 & 1.034 \\
CEO Tenure & -.034 & -.065 & 1.051 \\
Complexity & .037 & .023 & 1.036 \\
Munificence & .055 & .000 & 1.056 \\
Market Scope & -.008 & .241 & 1.030 \\
Main Effects & & & \\
\hline CFI & & $.241^{* *}$ & 1.030 \\
$\mathrm{R}^{2}$ & .012 & .068 & \\
$\Delta \mathrm{R}^{2}$ & & $.056^{\star \star}$ & \\
$\mathrm{F}$ & .359 & $1.871^{\star}$ & \\
$\Delta \mathrm{F}$ & & $12.316^{\star \star}$ & \\
\hline
\end{tabular}

${ }^{*} p<.05 ;{ }^{* *} p<.01$

To test our hypotheses examining how the fit between CFI and innovation activities influences organizational performance, we performed moderated hierarchical regression analysis. While the model is significant we must next determine if the relationships are in the hypothesized directions. To understand the specific relationships between CFI, innovation activity, and performance, we graphed the significant interaction terms in the regression equations (see Figures $I$ and 2). Table 4 shows the results of our analysis.

For both innovation variables the results were as anticipated. As predicted, we found a significant, positive relationship between the interaction of CFI and commitment to service innovation and performance $(b=.502, p<.001$; see Table 4). A graph of this interaction confirms our belief that higher performance will be associated with firms that combine higher levels of CFI with increasing levels of service innovation (see Figure 1). On the other hand, service firms that posses low levels of CFI see decreasing performance from their service innovation activity. Similarly, the interaction of CFl and delivery innovation, and firm performance was also significant and positive $(b=.207, \mathrm{p}<.01)$. A graph of the interaction shows that for those service firms requiring high levels of CFI, increasing levels of 
delivery innovation activity also lead to greater performance (see Figure 2). And again, firms low in CFI experience decreased performance from their pursuit of delivery innovation. Therefore, Hypothesis 3 and Hypothesis 4 are supported.

Table 4

Regression Results for CFI-Innovation Interactions and Performance

\begin{tabular}{|c|c|c|c|}
\hline Control and Main Effects & Step 1 & Step 2 & VIF \\
\hline Firm Size & .081 & .073 & 1.114 \\
\hline Dynamism & $-.117^{\star}$ & -.096 & 1.103 \\
\hline Industry Performance & $.228^{* *}$ & $.192^{\star *}$ & 1.045 \\
\hline CEO Tenure & .033 & -.002 & 1.065 \\
\hline Complexity & -.006 & -.034 & 1.056 \\
\hline Munificence & .020 & .033 & 1.060 \\
\hline Market Scope & -.017 & -.035 & 1.136 \\
\hline $\mathrm{CFI}$ & $.193^{\star \star}$ & $.240^{\star \star}$ & 1.145 \\
\hline Service Innovation & $-.144^{*}$ & $-.183^{\star \star}$ & 1.666 \\
\hline Delivery Innovation & .015 & .059 & 1.626 \\
\hline \multicolumn{4}{|l|}{ Interactions } \\
\hline $\mathrm{CFI} \times$ Service Innovation & & $.502^{\star \star}$ & 2.021 \\
\hline $\mathrm{CFI}$ x Delivery Innovation & & $.207^{\star \star}$ & 2.042 \\
\hline $\mathrm{R}^{2}$ & $.137^{\star \star}$ & $.280^{\star \star}$ & \\
\hline$\Delta R^{2}$ & & $.143^{\star *}$ & \\
\hline $\mathrm{F}$ & $3.209^{* *}$ & $6.480^{\star \star}$ & \\
\hline$\Delta F$ & & $19.842^{* \star}$ & \\
\hline
\end{tabular}

${ }^{\star} p<.05 ;{ }^{* *} p<.01$

Figure 1

Service Innovation X CFI

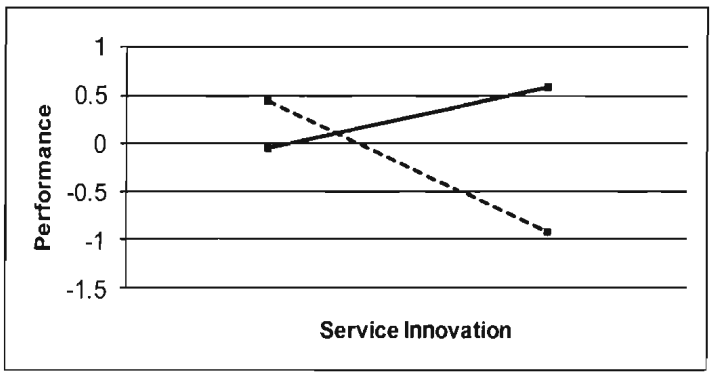

---Low CFI High CFI 
Figure 2

Delivery Innovation X CFI

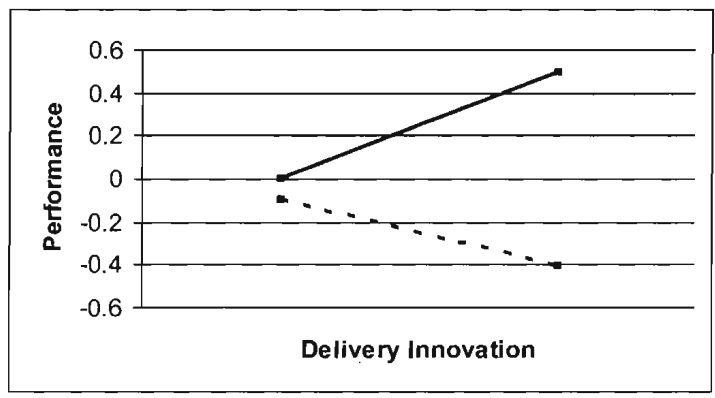

\section{Discussion}

We believe these findings have significant implications for both the study and practice of innovation within service firms. While much of the past research suggests that it is in the best interest of all firms to pursue innovation, recent thinking on this subject casts doubt on this prescription (e.g., Dess, et al., 1997; Wiklund, 1999). Indeed, scholars such as Yoon (1998) have observed that some firms may benefit more from innovation activities than others. This is particularly true for service firms, given that the intangible, process-oriented nature of their offering makes it difficult to protect innovations from imitation by competitors (Song, et al., 1999). Thus, only the presence of barriers to imitation can make innovation a desirable activity (Makadok, 1998). By extending transaction cost analysis to include the customer, our findings suggest that CFI can act as a barrier to imitation for service firms by creating status quo effects through increased switching costs for customers. In particular, we found CFI to be positively related to the commitment of two distinct types of service firm innovation activity (service and delivery), and that a proper fit among these variables was associated with positive changes in firm performance.

As predicted in Hypotheses I and 2, CFI was positively and significantly related to increased levels of service and delivery innovation. Taken together, these findings bolster the argument that when a service firm has intensive interactions with its customers, it impacts the perceived switching costs for its buyers. These costs become isolating mechanisms that induce firms to invest more in innovation activi- 
ties, for customers are more likely to adopt new services and/or delivery methods since they can do so without a lengthy and expensive evaluation search, and they will also be less likely to switch when a rival imitates the offering. In addition, our findings support a contingency explanation regarding the benefits of innovation activity. Results of Hypotheses 3 and 4 suggest that performance is increased when commitment to either service or delivery innovation is coupled with high levels of CFI. However, when high levels of CFI are not present, either type of commitment results in lower performance. Additional support for this contingency approach can be found by examining the relationship between service innovation and performance in the regression analysis in Table 4 . Though not hypothesized, a significant, negative relationship was found to exist between commitment to service innovation and performance $(b=-.144, p<.05)$. This suggests that, in general, higher activity levels in service innovation lead to lower levels of performance; it is only when this commitment is coupled with the appropriate level of CFI that performance is increased. Firms with high levels of CFI create competitive barriers, thereby allowing them to profit from their investments in innovation. On the other hand, service firms with low levels of CFI can apparently increase performance by economizing on such investments. Thus, the implication here is that managers within the service sector should resist the temptation to jump onto the innovation bandwagon without carefully considering the presence or absence of competitive barriers resulting from their firm's particular level of CFI.

Given the utility of CFI in understanding the pursuit and benefits of innovation activity in service organizations, there are a number of implications from our findings that involve extending the role of CFI into other areas of services. Though not hypothesized, we found a direct, positive relationship to exist between CFI and performance $(b=.193, p>.01$; see Table 4$)$. One possible explanation for this finding involves an extension of the switching costs argument. It may be that the creation of isolating mechanisms resulting from higher levels of CFI could afford such service organizations greater pricing power in general. Future research could examine whether there is a relationship between the level of CFI and prices differences among competing service firms.

A second implication involves the potential impact of CFI on the growth of a service firm; in particular, its ability to expand geographically. Service production processes that require high levels of CFI are typically more difficult to replicate than those requiring low levels of CFI (Mills \& Margulies, 1980). As a result, the geographic growth potential of high CFI service firms may be limited as compared to those low in CFI. Thus, a tradeoff may exist between CFI and geographic expan- 
sion. However, given that our findings strongly link CFI to innovation, the tradeoff for managers may boil down to a choice between growth through geographic expansion and growth through innovation. Using the CFI concept, future research could examine its impact on the nature of growth in service organizations.

Up to this point we have viewed CFI from the perspective of the level of firm-specific information gained by the customer. However, during this interaction the service firm is also acquiring and acting on information generated by its buyers (e.g., Skaggs \& Huffman, 2003). We believe it is likely that firms with high levels of CFI will be faced with processing a greater depth and variety of customer information. If true, then future research could examine whether the use of information technologies, such as customer relationship management (CRM) (Hansotia, 2002), are found to be present more often in these types of firms, and whether their presence leads to a performance advantage.

One additional avenue for future study would involve the relationship between business level strategies and the type of innovation service firms engage in. The present study controls for business level strategy by including market scope but it would be interesting to pursue the idea that differentiation strategies engage in service innovations while cost leadership strategies focus on delivery innovations.

Though we believe the present study provides support for our extension of CFI as a competitive barrier that can induce innovation activity in service firms, there are some limitations. First, we assumed that during their interaction with the firm, customers acquire knowledge about the firm. Therefore, we only measured the intensity and frequency of the interaction and not the actual knowledge that customers obtained. While the literature strongly suggests, and our data supports, the idea that intense interactions lead to this type of knowledge acquisition (e.g., Durkin, et al., 2003; Lengnick-Hall, 1996; Mills, 1986), we, nevertheless, did not directly measure it. Second, we assumed that service firms possessed an overall level of CFI with their customers. While this is true for many service organizations, it is possible that a firm could have multiple "ports" available to the customer, each with different levels of CFI. At issue is not the validity of our CFI measure. Given the continuous nature of the construct, we feel confident that CEOs of firms with multiple ports can reasonably derive an overall level of CFI for their firms. Furthermore, the sample restriction of single-industry dominant firms further helps to reduce the occurrence of multiple ports. Rather, at issue is whether a more narrowly-focused measure of CFI could uncover more specific, fine-grained relationships. For example, by ascertaining the levels of CFI for each port of entry into a service firm, one could determine whether particular ports are more essential in creating switching costs for custom- 
ers. We hope that future research will examine this possibility. One final limitation of our study lies in the fact that we did not measure levels of tangible vs. intangible characteristics within our sample firms. Although services are defined as offering an intangible process as the product, it is possible that CFI might be more or less important, depending on the level of tangibility of the characteristics of the offering. This issue might be explored in future studies.

\section{Conclusion}

There is consensus within the innovation literature that competitive barriers are necessary for successful innovation. However, many have suggested that due to the intangibility of the offering, such barriers are difficult to erect in service firms (e.g., Song, et al., 1999). This study examines CFI as one possible way for service firms to erect barriers and protect their innovation investments. The support of our hypotheses suggests that in fact high levels of CFI have a greater commitment to innovation activities. In particular, the results suggest that high levels of CFI act to create isolating mechanisms in the form of perceived customer switching and evaluation costs, which reduce the risk of customer defection as competitors introduce imitations into the marketplace. Service firms requiring high level of CFI respond to this risk reduction by committing greater resources to innovation in new services and delivery methods, which in turn create a performance advantage. We believe these findings represent an important step forward in understanding the drivers of innovation in services. We also believe our results should cause researchers and practitioners alike to reconceptualize the role of the service production process as both output function and competitive barrier. In the end, it is our hope that the present study will encourage others to investigate the dynamics driving the strategies of service organizations. Given their importance in the global economy, we believe such investigations are warranted.

\section{References}

Bagozzi, R., \& Phillips, L. (1982). Representing and testing organizational theories: A holistic construct. Administrative Science Quarterly, 27, 459-489.

Bantel, K., \& Jackson, S. (1989). Top management and innovations in banking: Does the composition of the top team make a difference? Strategic Management Journal, 10, 107-124.

Barringer, B. R., \& Bluedorn, A. C. (1999). The relationship between corporate entrepreneurship and strategic management. Strategic Management Journal, 20, $421-444$. 
Barris, R. (1986). Towards a theory of innovation in services. Research Policy, 15, 161-173.

Berry, L., Parasuraman, A., \& Zeithaml,V. (2003). Ten lessons for improving service quality. Marketing Science Institute, Report no. 93-104.

Bolton, R. N., Lemon, K. N., \& Verhoef, P. C. (2004). The theoretical underpinnings of customer asset management: a framework and propositions for future research. Journal of the Academy of Marketing Science, 32, 271-292.

Boyd, B. (1990). Corporate linkages and organizational environments: A test of the resource dependence model. Strategic Management Journal, 11, 419-430.

Brush, T. H., \& Artz, K. W. (1999). Toward a contingent resource-based theory: The impact of information asymmetry on the value of capabilities in veterinary medicine. Strategic Management Journal, 20, 223-250.

Craft, S. H.(2004). The international consumer market segmentation managerial decision-making process. SAM Advanced Management, 69, 40-46.

Damanpour, F., \& Shanthi, G. (2001). The dynamics of the adoption of product and process innovations in organizations. Journal of Management Studies, 3, 23-42.

Dess, G. G., Lumpkin, G. T., \& Covin, J. G. (1997). Entrepreneurial strategy making and firm performance: Tests of contingency and configurational models. Strategic Management Journal, 18, 677-695.

Dillman, D. A. (1978). Mail and telephone surveys: The total design method. New York: Wiley.

Durkin, M., McCartan-Quinn, D., O’Donnell, A., \& Howcroft, B. (2003). Retail bank customer preferences: Personal and remote interactions. International Journal of Retail \& Distribution Management, 31, 177-190.

Eriksson, K., \& Vaghult, A. L. (2000). Customer retention, purchasing behavior and relationship substance in professional services. Industrial Marketing Management, 29, 363-372.

Fornell, C. R., \& Larcker, D. F.(1981). Two structural equation models with unobservable variables and measurement error. Journal of Marketing Research, 18, $39-50$.

Gotlieb, J., Levy, M., Grewal, D., \& Lindsey-Mullikin, J. (2004). An examination of moderators of the effects of customers' evaluation of employee courtesy on attitude toward the service firm. Journal of Applied Social Psychology, 34, 825847.

Gourville, J. T. (2007, June). Eager sellers and stony buyers: Understanding the psychology of new-product adoption. Harvard Business Review, 98-106.

Hansotia, B. (2002). Gearing up to CRM: Antecedents to successful implementation. The Journal of Database Marketing, 10, 121-123. 
Hitt, M. A., Bierman, L., Shimizu, K., \& Kochhar, R. (2001). Direct and moderating effects of human capital on strategy and performance in professional service firms: A resource-based perspective. Academy of Management Journal, 44, $13-$ 32.

Huselid, M. A. (1995). The impact of human resource management practices on turnover, productivity, and corporate financial performance. Academy of Management Journal, 38, 635-673.

John, G., \& Weitz, B. (1988, Fall). Forward integration into distribution: Empirical test of transaction cost analysis. Journal of Law, Economics, and Organizations, 121-139.

Jones, M. A., Mothersbaugh, D. L., \& Beatty, S. E. (2000). Switching barriers and repurchase intentions in services. Journal of Retailing, 76(2), 259-274.

Kahneman, D., Knetsch, J. L., \& Thaler, R. H. (1991). Anomalies: The endowment effect, loss aversion, and status quo bias. Journal of Economic Perspectives, 5, 193-206.

Kahneman, D., \& Tversky, A. (1979). Prospect theory: An analysis of decision under risk. Econometrica, 47, 263-291.

Kerin, R., Varadarajan, R.R., \& Peterson, R. ( 1992). First-mover advantage: A synthesis, conceptual framework, and research propositions. Journal of Marketing, $56,33-52$.

Lance, C. E., \& Vandenberg, R. J. (2002). Confirmatory factor analysis. In F. Drasgow \& N. Schmitt (Eds.), Advances in measurement and data analysis (pp. 221254). San Francisco: Jossey-Bass.

Lee, H., Smith, K. G., Grimm, C. M., \& Schomburg, A. (2000). Timing, order and durability of new product advantages with imitation. Strategic Management Journal, 21, 23-30.

Lehmann, E., \& Neuberger, D. (2001). Do lending relationships matter? - Evidence from bank survey data in Germany. Journal of Economics Behavior and Organizations, 45(4), 339-360.

Lengnick-Hall, C. A. (1996). Customer contributions to quality: A different view of the customer-oriented firm. Academy of Management Review, 21, 791-824.

Lieberman, M. B., \& Montgomery, D. B. (1988). First-mover advantages. Strategic Management Journal, 9, 41-58.

Lieberman, M. B., \& Montgomery, D. B. (1998). First-mover (dis)advantages: Retrospective and link with the resource-based view. Strategic Management Journal, 19, 1111-1125. 
Lumpkin, G. T., \& Dess, G. G. (1996). Clarifying the entrepreneurial orientation construct and linking it to performance. Academy of Management Review, $2 l$, 135-172.

Makadok, R. (1998). Can first-mover and early-mover advantages be sustained in an industry with low barriers to entry/imitation? Strategic Management Journal, 19, 683-696.

Miles, I. (2007). Research and development (R\&D) beyond manufacturing: The strange case of services R\&D. $R \& D$ Management, 37, 249.

Miller, D. C. (1991). Handbook of research design and social measurement. Newbury Park, CA: Sage.

Miller, D., \& Friesen, P. H. (1978). Archetypes of strategy formulation. Management Science, 24, 921-933.

Mills, P. K. (1986). Managing service industries: Organizational practices in a postindustrial economy. Cambridge, MA: Ballinger.

Mills, P. K., \& Margulies, N. (1980). Towards a core typology of service organizations. Academy of Management Review, 5, 255-265.

Normann, R. (1984). Service management: Strategy and leadership in service businesses. Chichester: Wiley .

Nunnally, J. C. (1978). Psychometric theory. New York: McGraw-Hill.

O'Brien, J.P. (2003). The capital structure implications of pursuing a strategy of innovation. Strategic Management Journal, 24, 415-431.

Ouchi, W.G. (1984). The M-Form society. Reading, MA: Addison-Wesley.

Parasuraman, A., Zeithaml, V. A., \& Berry, L. L. (1985). A conceptual model of service quality and its implications for future research. Journal of Marketing, $49,41-50$.

Podsakoff, P., MacKenzie, S., Lee, J., \& Podsakoff, N. (2003). Common method biases in behavioral research: A critical review of the literature and recommended remedies. Journal of Applied Psychology, 88, 878-904.

Porter, M. (1985). Competitive advantage. New York, NY: Free Press.

Rumelt, R. P. (1974). Strategy, structure, and economic performance. Cambridge, MA: Harvard University Press.

Rumelt, R. P. (1987). Theory, strategy, and entrepreneurship. In D. J. Teece (Ed.), The competitive challenge: Strategies for industrial innovation and renewal. Cambridge, MA: Ballinger.

Shostack, G. L. (1987). Service positioning through structural change. Journal of Marketing, 51, 34-43. 
Skaggs, B. C., \& Huffman, T. R. (2003). A customer interaction approach to strategy and production complexity alignment in service firms. Academy of Management Journal, 46, 775-787.

Skaggs, B. C., \& Youndt, M. (2004). Strategic positioning human capital and performance in service organizations: A customer interaction approach. Strategic Management Journal, 25, 85-99.

Smith, A. K., Bolton, R. N., \& Wagner, J. (1999). A model of customer satisfaction with service encounters involving failure and recovery. Journal of Marketing Research, 36, 356-372.

Song, X. M., Di Benedetto, C. A., \& Zhao, Y. L. (1999). Pioneering advantages in manufacturing and service industries: Empirical evidence from nine countries. Strategic Management Journal, 20, 811-836.

Subramaniam, M., \& Youndt, M. (2005). The influence of intellectual capital on the types of innovative capabilities. Academy of Management Journal, 48, 450-463.

Sundbo, J. (1997). Management of innovation in services. The Service Industry Journal, 17, 432-455.

Tansik, D. A. (1990). Balance in service systems designs. Journal of Business Research, 20, 55-61.

Thompson, J. D. (1967). Organizations in action. New York, NY: McGraw-Hill.

Wiklund, J. (1999). The sustainability of the entrepreneurial orientation-performance relationship. Entrepreneurship Theory and Practice, 24, 37-48.

Williamson O. E. (1979). Transaction-cost economics: The governance of contractual relations. Journal of Law and Economics, 22, 232-261.

Williamson, O. E. (1985). The economic institutions of capitalism: Firms, markets, relational contracting. New York 0: The Free Press.

Yoon, S. (1998). A successful strategy of follow the leader combined with cultural adaptation: A food company case. International Studies of Management and Organizations, 28, 49-57.

Zhang, Y., \& Rajagopalan, N. (2004). When the known devil is better than an unknown god: An empirical study of the antecedents and consequences of relay CEO successions. Academy of Management Journal, 47, 483-500. 


\section{Appendix}

\section{Questionnaire Items and Factor Loadings*}

123

\section{SERVICE INNOVATION}

Relative to our competitors...

1. My firm allocates substantial financial resources to developing new innovative services.

2. In the past 5 years my firm has developed many new innovative services. .840

3. My firm is very often the first to introduce new services into the market.

4. My firm is considered to be "cutting edge" when it comes to developing new services.

5. Developing unique service offerings is a priority of this firm.

6. Our firm strives to develop new services that are different from our competitors' offerings.

\section{DELIVERY INNOVATION}

Relative to our competitors...

1. My firm is committed to developing better ways to deliver our services to our customers.

2. My company strives to develop unique ways to deliver our services.

3. In the past 5 years my firm has increased its overall commitment to developing innovative ways to deliver our services.

\section{CUSTOMER-FIRM INTERACTION (CFI)}

Relative to our competitors, during service production...

1. Employees producing the service spend the majority of their daily working time in face-to-face contact with customers.

2. Employees producing the senvice spend a lot of time dealing directly with the customer.

3. Our firm more often meets directly with our customers to exchange information when producing the service.

4. The service we provide requires that customers work closely with employees within this company.

Eigenvalues

$\%$ of variance explained 


\section{Biographical Sketches of Authors}

Tammy Huffman is an Associate Professor of Management at the Woodbury School of Business at Utah Valley University. She received her Ph.D. from the Gatton College of Business and Economics at the University of Kentucky. Dr. Huffman's recent research has focused on changes in information asymmetry and its impact on service industries.

Bruce Skaggs is an Associate Professor of Strategic Management at the Isenberg School of Management at the University of Massachusetts Amherst. $\mathrm{He}$ received his Ph.D. from the Smeal College of Business at the Pennsylvania State University. Much of Dr. Skaggs' research involves examining how service organizations identify and leverage their competencies to achieve competitive advantage. $\mathrm{He}$ is also currently involved in projects that explore how these firms build and leverage knowledge. 
